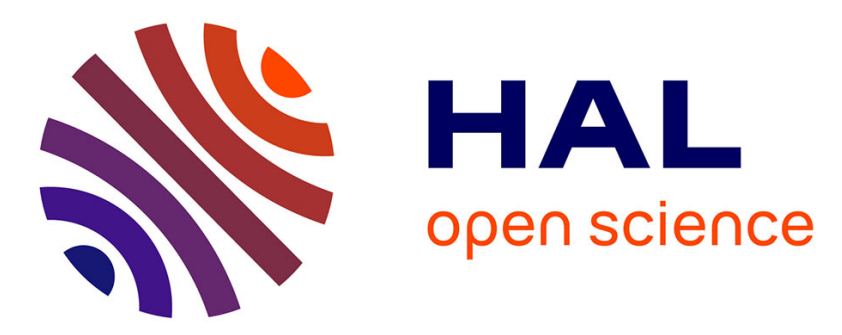

\title{
Three new flavonoid glycosides from the aerial parts of Graptophyllum grandulosum Turril ( Acanthaceae )
}

Cyrille Ngoufack Tagousop, David Ngnokam, Dominique Harakat, Laurence Voutquenne-Nazabadioko

\section{To cite this version:}

Cyrille Ngoufack Tagousop, David Ngnokam, Dominique Harakat, Laurence VoutquenneNazabadioko. Three new flavonoid glycosides from the aerial parts of Graptophyllum grandulosum Turril ( Acanthaceae ). Phytochemistry Letters, 2017, 19, pp.172-175. 10.1016/j.phytol.2016.12.035 . hal-01996298

\section{HAL Id: hal-01996298 \\ https://hal.univ-reims.fr/hal-01996298}

Submitted on 28 Oct 2021

HAL is a multi-disciplinary open access archive for the deposit and dissemination of scientific research documents, whether they are published or not. The documents may come from teaching and research institutions in France or abroad, or from public or private research centers.
L'archive ouverte pluridisciplinaire HAL, est destinée au dépôt et à la diffusion de documents scientifiques de niveau recherche, publiés ou non, émanant des établissements d'enseignement et de recherche français ou étrangers, des laboratoires publics ou privés. 
archives-ouvertes

\section{Three new flavonoid glycosides from the aerial parts of Graptophyllum grandulosum Turril ( Acanthaceae )}

Cyrille Ngoufack Tagousop, David Ngnokam, Dominique Harakat, Laurence Voutquenne-Nazabadioko

\section{To cite this version:}

Cyrille Ngoufack Tagousop, David Ngnokam, Dominique Harakat, Laurence VoutquenneNazabadioko. Three new flavonoid glycosides from the aerial parts of Graptophyllum grandulosum Turril ( Acanthaceae ). Phytochemistry Letters, Elsevier, 2017, 19, pp.172-175. 10.1016/j.phytol.2016.12.035 . hal-01996298

\section{HAL Id: hal-01996298 \\ https://hal.univ-reims.fr/hal-01996298}

Submitted on 28 Oct 2021

HAL is a multi-disciplinary open access archive for the deposit and dissemination of scientific research documents, whether they are published or not. The documents may come from teaching and research institutions in France or abroad, or from public or private research centers.
L'archive ouverte pluridisciplinaire HAL, est destinée au dépôt et à la diffusion de documents scientifiques de niveau recherche, publiés ou non, émanant des établissements d'enseignement et de recherche français ou étrangers, des laboratoires publics ou privés. 


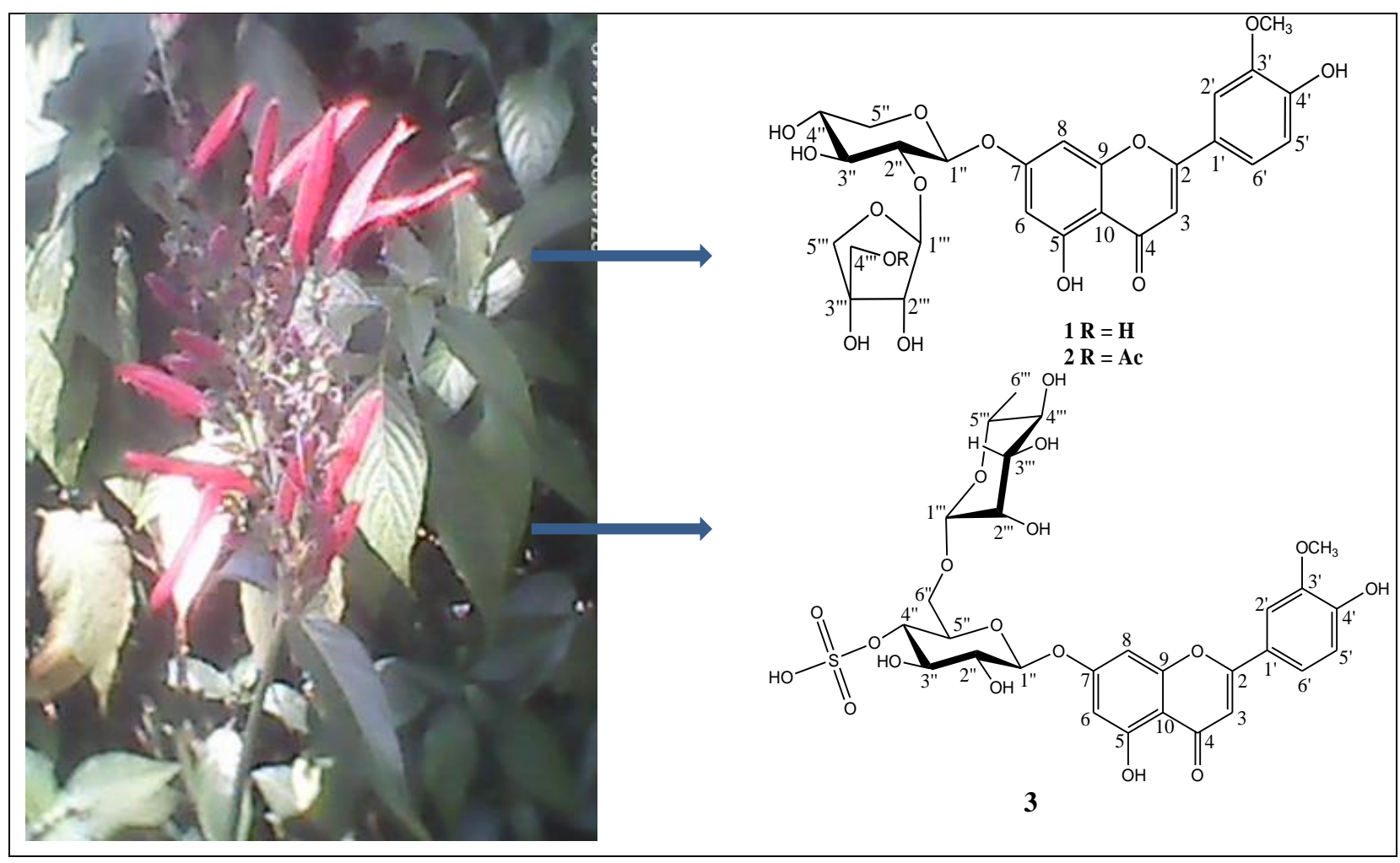




\section{Highlights}

$>$ Granduloside A-C, three new flavonoids glycosides were isolated from the aerial parts of Graptophyllum grandulosum Turill.

$>$ The structure was characterized by extensive 2D-NMR studies

$>$ Four known compounds were also isolated from this plant 


\title{
Three new flavonoid glycosides from the aerial parts of Graptophyllum grandulosum Turril (Acanthaceae)
}

\author{
Cyrille NGOUFACK TAGOUSOP ${ }^{\mathrm{a}}$, David NGNOKAM ${ }^{\mathrm{a}^{*}}$, Dominique HARAKAT ${ }^{\mathrm{b}}$ and \\ Laurence VOUTQUENNE-NAZABADIOKO ${ }^{c}$ \\ ${ }^{\mathrm{a}}$ Faculty of Science, Department of Chemistry, University of Dschang, P.O. Box 67. \\ Dschang, Cameroon \\ ${ }^{\text {b}}$ Service Commun d'Analyses, Institut de Chimie Moléculaire de Reims (ICMR), CNRS \\ UMR 7312, Bat. 18 B.P. 1039, 51687 Reims Cedex 2, France \\ ${ }^{c}$ Groupe Isolement et Structure, Institut de Chimie Moléculaire de Reims (ICMR), CNRS \\ UMR 7312, Bat. 18 B.P. 1039, 51687 Reims Cedex 2, France
}

\section{Corresponding authors:}

* Professor David Ngnokam, Laboratory of Environmental and Applied Chemistry, Department of Chemistry, Faculty of Science, University of Dschang, PO. Box 67, Dschang, Cameroon, Tel: +237 696710 992. E-mail: dngnokam@yahoo.fr/ngnokam@univ-dschang.org 


\begin{abstract}
Grandulosides A-C, three new flavonoid glycosides, were isolated from the aerial parts of Graptophyllum grandulosum Turill and identified as chrysoeriol-7- $O-\beta$-Dapiofuranosyl-( $1 \rightarrow 2)-\beta$-D-xylopyranoside (1), chrysoeriol-7- $O$-[4, ' $-O$-acetyl- $\beta$-D-

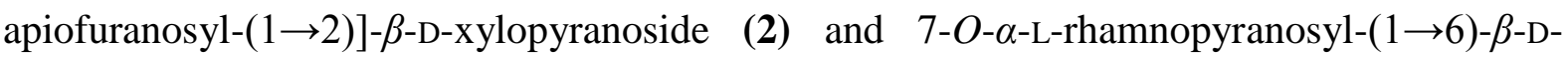
(4',-hydrogeno sulfate) glucopyranoside (3). Four known compounds, chrysoeriol-7- $O-\beta$-Dxyloside (4), isorhamnetin-3- $O$ - $\alpha$-L-rhamnopyranosyl-( $1 \rightarrow 6)-\beta$-D-glucopyranoside (5), luteolin-7- $O-\beta$-D-apiofuranosyl-( $(1 \rightarrow 2)-\beta$-D-xylopyranoside $(\mathbf{6})$ and sucrose (7) were also obtained. The structures of these compounds were established by interpretation of their spectral data, mainly HR-TOFESIMS, 1D-NMR $\left({ }^{1} \mathrm{H},{ }^{13} \mathrm{C}\right)$ and 2D-NMR (COSY, NOESY, HSQC and HMBC) and by comparison with the literature data.
\end{abstract}

Keywords: Acanthaceae, Graptophyllum grandulosum, flavonoid glycosides, granduloside. 


\section{Introduction}

The genus Graptophyllum is a member of the Acanthaceae family and occurs mainly in tropical and some temperate environments. Globally, there are about 15 species of Graptophyllum, comprising shrubs or small trees that predominantly grow in the Pacific region and West and Central Africa (Barker 1986). Many species of this genus, such as Graptophyllum pictum, are used as medicinal plants in folk medicine (Perry, 1980; Kasahara and Mangunkawatjia, 1986). Previous studies of this genus revealed the presence of alkaloids, triterpenes, coumarins and flavonoids (Corrêa and Alcântara, 2012). In the course of our continuing search for secondary metabolites of biological importance from medicinal plants, we investigated the $n$-BuOH extract of the aerial parts of Graptophyllum grandulosum and isolated three new flavonoid glycosides whose structures are discussed in the present report.

\section{Results and discussion}

Purification of the $n$ - $\mathrm{BuOH}$ soluble fraction of the crude $\mathrm{MeOH}$ extract afforded three new compounds, grandulosides A, B and C (1-3), and four known compounds (4-7). The known compounds were identified as chrysoeriol-7- $O-\beta$-D-xyloside (4) (Markham and Chari,1982 ; Markham et al., 1978), isorhamnetin-3-O- $\alpha$-L-rhamnopyranosyl-(1 $\rightarrow 6)-\beta$-Dglucopyranoside (5) (Mona-antonia and Hanns, 1999), luteolin-7- $O-\beta$-D-apiofuranosyl$(1 \rightarrow 2)-\beta$-D-xylopyranoside (6) (Koffi et al., 2013) and sucrose (7) (Hee-Jeong et al., 2014) by comparison of their spectroscopic data with those reported in the literature.

Compound 1 was obtained as a yellow powder that reacted positively with Shinoda and Molisch reagents, thus revealing the presence of a glycosylated flavonoid. Its molecular formula $\mathrm{C}_{26} \mathrm{H}_{28} \mathrm{O}_{14}$ was determined on the basis of a pseudo-molecular ion peak at $\mathrm{m} / \mathrm{z}$ $587.1370[\mathrm{M}+\mathrm{Na}]^{+}$(calcd. for $\mathrm{C}_{26} \mathrm{H}_{28} \mathrm{O}_{14} \mathrm{Na}$ 587.1377) in its HR-TOFESIMS spectrum. The ${ }^{1} \mathrm{H}-\mathrm{NMR}$ (Table 1) spectrum of $\mathbf{1}$, showed signals at $\delta_{\mathrm{H}:} 6.70(\mathrm{H}-3, \mathrm{~s}), 6.45(\mathrm{H}-6, \mathrm{~d}, J=2.2$ Hz), $6.77(\mathrm{H}-8, \mathrm{~d}, J=2.2 \mathrm{~Hz}), 7.52\left(\mathrm{H}-2^{\prime}, \mathrm{d}, J=2.1 \mathrm{~Hz}\right), 6.95\left(\mathrm{H}-5^{\prime}, \mathrm{d}, J=8.2 \mathrm{~Hz}\right)$ and 7.56 (H-6', dd, $J=8.2,2.1 \mathrm{~Hz}$ ). These protons showed correlations in the HSQC spectrum with the carbons at $\delta_{\mathrm{C}:} 104.5(\mathrm{C}-3), 100.9(\mathrm{C}-6), 95.9(\mathrm{C}-8), 110.4\left(\mathrm{C}-2^{\prime}\right), 116.7\left(\mathrm{C}-5^{\prime}\right)$ and 121.9 (C-6'), respectively, indicating a 3',4',5,7-tetrasubstituted flavone skeleton. The HMBC correlation of a methyl signal at $\delta_{\mathrm{H}} 3.98$ (s) with the carbon signal at $\delta_{\mathrm{C}} 149.5$ indicated the presence of a methoxyl group at C-3'. Thus the aglycone is 5,7,4'-trihydroxy-3'methoxyflavone (chrysoeriol) (Facundo et al., 2012). The ${ }^{1} \mathrm{H}-\mathrm{NMR}$ spectrum also exhibited the anomeric protons of two sugar units at $\delta_{\mathrm{H}} 5.16\left(\mathrm{H}-1{ }^{\prime},, \mathrm{d}, J=7.2 \mathrm{~Hz}\right)$ and $\delta_{\mathrm{H}} 5.46(\mathrm{H}-1$ ', , $\mathrm{d}, J=1.3 \mathrm{~Hz}$ ). Correlations in the HSQC spectrum readily identified the corresponding 
anomeric carbons at $\delta_{\mathrm{C}} 100.6\left(\mathrm{C}-1\right.$ '") and $\delta_{\mathrm{C}} 110.0$ (C-1"'), respectively. Complete assignment of the protons and carbons of the sugar units was achieved by analysis of COSY, ${ }^{1} \mathrm{H}-{ }^{1} \mathrm{H}$, NOESY, HSQC and HMBC spectra. The sugars were identified as a xylopyranose (from $\delta_{\mathrm{H}} 5.16$ ) and an apiofuranose (from $\delta_{\mathrm{H}} 5.46$ ) characterized by its quaternary carbon C3','. Acid hydrolysis of $\mathbf{1}$ afforded xylose and apiose which were detected by TLC. The Dconfiguration of these sugars was confirmed by GC-MS after derivatization. Their anomeric configuration was determined to be $\beta$ from the ${ }^{3} J_{\mathrm{H} 1-\mathrm{H} 2}$ values of the anomeric proton signals and the chemical shifts of the anomeric carbons (Agrawal, 1992). The HMBC spectrum showed a correlation between xylose $\mathrm{H}-1$ and $\mathrm{C}-7$ of the aglycone, confirming its direct attachment to the aglycone. The deshielded nature of C-2"' $\left(\delta_{\mathrm{C}} 78.6\right)$ suggested a substitution at this position. This was readily confirmed by the HMBC correlation from apiose $\mathrm{H}-1$ to carbon C-2"' $\left(\delta_{\mathrm{C}} 78.6\right)$ of xylose. The NMR spectral data of compound $\mathbf{1}$, without the signal of the methoxyl group are in good agreement with those reported (Koffi et al., 2013). Thus the structure of compound $\mathbf{1}$, granduloside $\mathrm{A}$, is chrysoeriol-7- $O-\beta$-D-apiofuranosyl-( $1 \rightarrow 2)-\beta$ D-xylopyranoside.

Compound $\mathbf{2}$ was obtained as a yellow amorphous powder that reacted positively with Shinoda and Molisch reagents. Its molecular formula $\mathrm{C}_{28} \mathrm{H}_{30} \mathrm{O}_{15}$ was determined on the basis of a pseudo-molecular ion peak at $m / z, 629.1471[\mathrm{M}+\mathrm{Na}]^{+}$(calcd. for $\mathrm{C}_{28} \mathrm{H}_{30} \mathrm{O}_{15} \mathrm{Na} 629.1482$ ) in its positive HR-TOFESIMS spectrum. The ${ }^{1} \mathrm{H}-\mathrm{NMR}$ and ${ }^{13} \mathrm{C}-\mathrm{NMR}$ spectra of 2 (Table 1) were very similar to those of compound $\mathbf{1}$, except for the presence of an acetate group $\left[\delta_{\mathrm{C}}\right.$ $\left.172.5(\mathrm{CO}), 20.5\left(\mathrm{CH}_{3}\right)\right]$ in the ${ }^{13} \mathrm{C}-\mathrm{NMR}$ spectrum. The deshielding of C-4", $\left(\delta_{\mathrm{C}} 68.3\right)$ of apiose and the HMBC correlations between protons $2 \mathrm{H}-4$ "' $\left(\delta_{\mathrm{H}} 4.12,4.07\right)$ and the ester carbonyl carbon at $\delta_{\mathrm{C}} 172.5$ confirmed the presence of an apiose C-4",' acetate. Acetylation at this position has already been reported in acacetin-7-O-[4"',-O-acetyl- $\beta$-D-apiofuranosyl$(1 \rightarrow 3)]-\beta$-D-xylopyranoside by Zhang et al. 2014. Thus compound 2, granduloside B. is chrysoeriol-7- $O$-[4,' $-O$-acetyl- $\beta$-D-apiofuranosyl- $(1 \rightarrow 2)]-\beta$-D-xylopyranoside.

Compound $\mathbf{3}$ was obtained as a yellow amorphous powder that reacted positively with Shinoda and Molisch reagents. Its molecular formula $\mathrm{C}_{28} \mathrm{H}_{31} \mathrm{O}_{18} \mathrm{~S}$ was determined on the basis of a pseudo-molecular ion peak at $\mathrm{m} / z$ 687.1226 [M-H] ${ }^{-}$(calcd. for $\mathrm{C}_{28} \mathrm{H}_{31} \mathrm{O}_{18} \mathrm{~S}$ 687.1231) in its negative HR-TOFESIMS spectrum. The ${ }^{1} \mathrm{H}-\mathrm{NMR}$ and ${ }^{13} \mathrm{C}-\mathrm{NMR}$ spectra of 3 (Table 1), revealed the presence of a 5,7,4'-trihydroxy-3'-methoxyflavone (chrysoeriol) (Facundo et al., 2012) as in compound 1. In addition, its ${ }^{1} \mathrm{H}-\mathrm{NMR}$ spectrum showed the anomeric protons of two sugar units at $\delta_{\mathrm{H}} 5.15\left(\mathrm{H}-1{ }^{\prime}, \mathrm{d}, J=7.7 \mathrm{~Hz}\right)$ and $\delta_{\mathrm{H}} 4.74\left(\mathrm{H}-1{ }^{\prime},{ }^{\prime}, d, J\right.$ 
$=1.3 \mathrm{~Hz}$ ) which had HSQC correlations with the corresponding anomeric carbons at $\delta_{\mathrm{C}} 104.0$ (C-1') and 102.6 (C-1'"'), respectively. The complete assignment of the protons and carbons of a glucopyranose (from $\delta_{\mathrm{H}} 5.15$ ) and a rhamnopyranose (from $\delta_{\mathrm{H}} 4.75$ ), with its methyl signal at $\delta_{\mathrm{H}} 1.21$, was achieved as for compound $\mathbf{1}$. The sugar composition was confirmed by TLC, after acid hydrolysis, to be glucose and rhamnose. Their respective D and L absolute configurations were established by GC-MS after derivatization. The anomeric proton configurations of glucose and rhamnose were assigned as $\beta$ and $\alpha$, respectively from the ${ }^{3} J_{\mathrm{H} 1-}$ $\mathrm{H} 2$ values of the anomeric protons and the chemical shifts of the anomeric carbons (Agrawal, 1992). An HMBC correlation between H-1", of glucose and C-7 of the aglycone confirmed the direct attachment of glucose to the aglycone. The correlation between H-1 ", of rhamnose and C-6" of glucose established the connectivity of the two sugar units. The deshielding of C-4"' $\left(\delta_{\mathrm{C}} 77.5\right)$ indicated that it was linked to an electron withdrawing group, identified as a hydrogen sulfate $\left(\mathrm{HSO}_{4}^{-}\right)$group by mass spectroscopy. Thus compound $\mathbf{3}$, granduloside $\mathrm{C}$, is chrysoeriol-7- $O$ - $\alpha$-L-rhamnopyranosyl $(1 \rightarrow 6)-\beta$-D-(4' '-hydrogeno sulfate) glucopyranoside.
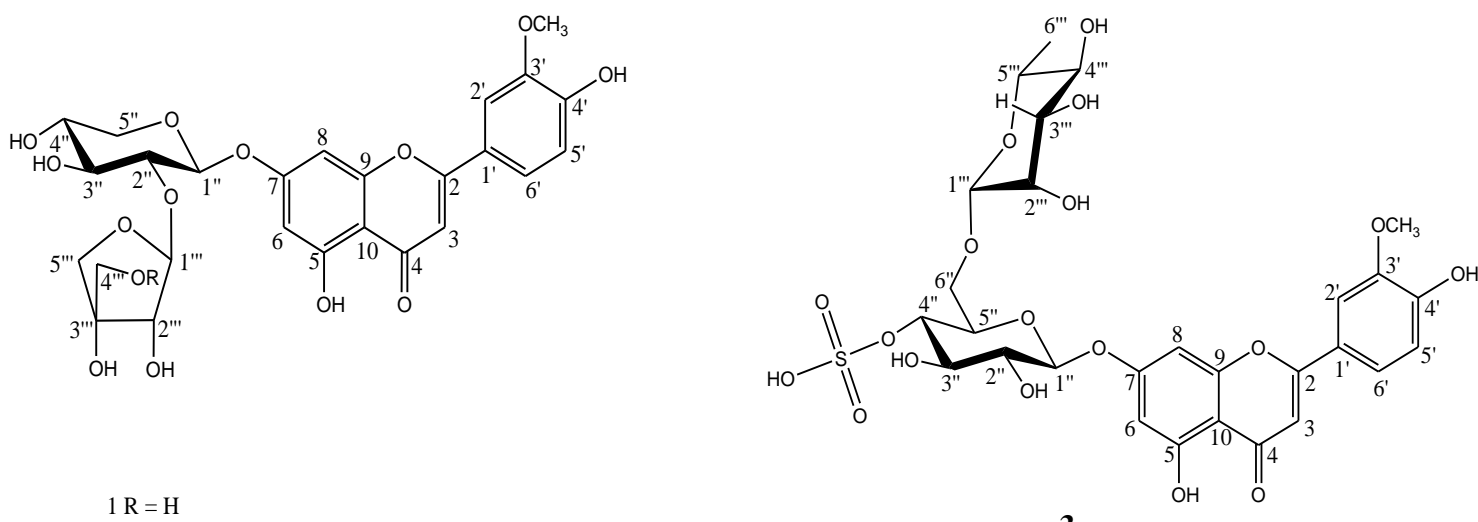

$$
\begin{aligned}
& 1 \mathrm{R}=\mathrm{H} \\
& 2 \mathrm{R}=\mathrm{Ac}
\end{aligned}
$$

3

Fig.1. Structures of compounds 1-3 isolated from the $n$-BuOH soluble extract of Graptophyllum grandulosum 
Table 1: ${ }^{1} \mathrm{H}-\mathrm{NMR}(600 \mathrm{MHz})$ and ${ }^{13} \mathrm{C}-\mathrm{NMR}(150 \mathrm{MHz})$ data of compounds $\mathbf{1 - 3}$ in $\mathrm{CD}_{3} \mathrm{OD}$

\begin{tabular}{|c|c|c|c|c|c|c|}
\hline \multirow[t]{2}{*}{$\mathrm{N}^{\mathrm{O}}$} & \multicolumn{2}{|r|}{1} & \multicolumn{2}{|r|}{2} & \multicolumn{2}{|r|}{3} \\
\hline & ${ }^{13} \mathrm{C}$ & ${ }^{\mathrm{I}} \mathrm{H}(\mathrm{J}$ in $\mathrm{Hz})$ & ${ }^{13} \mathrm{C}$ & ${ }^{1} \mathrm{H}(J$ in $\mathrm{Hz})$ & ${ }^{13} \mathrm{C}$ & ${ }^{1} \mathrm{H}(J$ in $\mathrm{Hz})$ \\
\hline & \multicolumn{2}{|c|}{ Aglycon } & \multicolumn{2}{|c|}{ Aglycon } & \multicolumn{2}{|c|}{ Aglycon } \\
\hline 1 & - & - & - & - & - & - \\
\hline 2 & 166.6 & - & 166.8 & - & 166.8 & - \\
\hline 3 & 104.5 & $6.70(1 \mathrm{H}, \mathrm{s})$ & 104.6 & $6.73(1 \mathrm{H}, \mathrm{s})$ & 104.5 & $6.73(1 \mathrm{H}, \mathrm{s})$ \\
\hline 4 & 184.0 & - & 184.1 & - & 184.1 & - \\
\hline 5 & 162.9 & - & 163.0 & - & 163.1 & - \\
\hline 6 & 100.9 & $6.45(1 \mathrm{H}, \mathrm{d}, 2.1)$ & 100.9 & $6.44(1 \mathrm{H}, \mathrm{d}, 2.0)$ & 101.1 & $6.56(1 \mathrm{H}, \mathrm{d}, 2.1)$ \\
\hline 7 & 164.4 & - & 164.4 & - & 164.0 & - \\
\hline 8 & 95.9 & $6.77(1 \mathrm{H}, \mathrm{d}, 2.1)$ & 95.7 & $6.78(1 \mathrm{H}, \mathrm{d}, 2.0)$ & 96.2 & $6.84(1 \mathrm{H}, \mathrm{d}, 2.1)$ \\
\hline 9 & 158.9 & - & 159.0 & - & 159.0 & - \\
\hline 10 & 107.0 & - & 107.1 & - & 107.2 & - \\
\hline 1 ' & 123.4 & - & 123.5 & - & 123.6 & - \\
\hline 2 ' & 110.4 & $7.52(1 \mathrm{H}, \mathrm{d}, 2.1)$ & 110.8 & $7.56(1 \mathrm{H}, \mathrm{d}, 2.0)$ & 110.8 & $7.55(1 \mathrm{H}, \mathrm{d}, 2.1)$ \\
\hline $3{ }^{\prime}$ & 149.5 & - & 149.6 & - & 149.6 & - \\
\hline $4^{\prime}$ & 152.3 & - & 152.3 & - & 152.3 & - \\
\hline 5 & 116.7 & $6.95(1 \mathrm{H}, \mathrm{d}, 8.4)$ & 116.8 & $6.97(1 \mathrm{H}, \mathrm{d}, 8.4)$ & 116.9 & $6.98(1 \mathrm{H}, \mathrm{d}, 8.4)$ \\
\hline $6{ }^{\prime}$ & 121.9 & $7.56(1 \mathrm{H}, \mathrm{dd}, 8.4,2.1)$ & 122.0 & $7.59(1 \mathrm{H}, \mathrm{dd}, 8.4,2.0)$ & 122.0 & $7.59(1 \mathrm{H}, \mathrm{d}, 8.4,2.1)$ \\
\hline \multirow[t]{2}{*}{$\mathrm{OCH}_{3}$} & 56.6 & $3.98(3 \mathrm{H}, \mathrm{s})$ & 56.7 & $4.00(3 \mathrm{H}, \mathrm{s})$ & 56.7 & $3.99(3 \mathrm{H}, \mathrm{s})$ \\
\hline & \multicolumn{2}{|l|}{ Xyl } & \multicolumn{2}{|l|}{ Xyl } & \multicolumn{2}{|l|}{ Glc } \\
\hline 1, & $\overline{100.6}$ & $5.16(1 \mathrm{H}, \mathrm{d}, 7.1)$ & $\overline{100.5}$ & $5.17(1 \mathrm{H}, \mathrm{d}, 7.3)$ & $\overline{100.9}$ & $5.15(1 \mathrm{H}, \mathrm{d}, 7.8)$ \\
\hline $2^{\prime \prime}$ & 78.6 & $3.68(1 \mathrm{H}, \mathrm{dd}, 9.0,7.1)$ & 77.8 & $3.71(1 \mathrm{H}, \mathrm{dd}, 9.1,7.3)$ & 74.5 & $3.61(1 \mathrm{H}, \mathrm{dd}, 9.1,7.8)$ \\
\hline $3 "$ & 77.9 & $3.63(1 \mathrm{H}, \mathrm{m})$ & 78.2 & $3.61(1 \mathrm{H}, \mathrm{m})$ & 76.8 & $3.84(1 \mathrm{H}, \mathrm{t}, 9.1)$ \\
\hline 4, & 70.9 & $3.62(1 \mathrm{H}, \mathrm{m})$ & 71.0 & $3.60(1 \mathrm{H}, \mathrm{m})$ & 77.5 & $4.32(1 \mathrm{H}, \mathrm{dd}, 9.9,9.1)$ \\
\hline \multirow[t]{2}{*}{5,} & 66.9 & $3.97(1 \mathrm{H}, \mathrm{m})$ & 67.0 & $3.97(1 \mathrm{H}, \mathrm{dd}, 10.9,4.3)$ & 75.3 & $3.89(1 \mathrm{H}, \mathrm{m})$ \\
\hline & & $3.48(1 \mathrm{H}, \mathrm{t}, 9.6)$ & & $3.48(1 \mathrm{H}, \mathrm{t}, 10.9)$ & & \\
\hline \multirow[t]{3}{*}{6 ', } & & & & & 67.1 & $4.10(1 \mathrm{H}, \mathrm{m})$ \\
\hline & & & & & & $3.68(1 \mathrm{H}, \mathrm{m})$ \\
\hline & \multicolumn{2}{|l|}{ Api } & \multicolumn{2}{|l|}{ Api } & \multicolumn{2}{|l|}{$\underline{\text { Rha }}$} \\
\hline 1, & $\overline{110.0}$ & $5.46(1 \mathrm{H}, \mathrm{d}, 1.7)$ & $\overline{110.3}$ & $5.49(1 \mathrm{H}, \mathrm{d}, \mathrm{sl})$ & $\overline{102.4}$ & $4.75(1 \mathrm{H}, \mathrm{d}, 1.3)$ \\
\hline 2, & 78.1 & $3.98(1 \mathrm{H}, \mathrm{m})$ & 78.5 & $3.87(1 \mathrm{H}, \mathrm{d}, 3.6)$ & 71.9 & $3.95(1 \mathrm{H}, \mathrm{dd}, 3.4,1.3)$ \\
\hline $3, \%$ & 80.7 & - & 79.0 & - & 72.3 & $3.72(1 \mathrm{H}, \mathrm{dd}, 9.5,3.4)$ \\
\hline \multirow[t]{2}{*}{4,} & 65.8 & $3.56(2 \mathrm{H}, \mathrm{sl})$ & 68.3 & $4.12(1 \mathrm{H}, \mathrm{d}, 11.3)$ & 74.2 & $3.32(1 \mathrm{H}, \mathrm{t}, 9.5)$ \\
\hline & & & & $4.07(1 \mathrm{H}, \mathrm{d}, 11.3)$ & & \\
\hline \multirow[t]{2}{*}{$5, \%$} & 75.4 & $4.05(1 \mathrm{H}, \mathrm{d}, 9.5)$ & 75.4 & $4.14(1 \mathrm{H}, \mathrm{d}, 9.6)$ & 69.8 & $3.42(1 \mathrm{H}, \mathrm{m})$ \\
\hline & & $3.84(1 \mathrm{H}, \mathrm{d}, 9.5)$ & & $3.86(1 \mathrm{H}, \mathrm{d}, 9.6)$ & & \\
\hline 6, & & & & & 17.9 & $1.21(3 \mathrm{H}, \mathrm{d}, 6.2)$ \\
\hline \multirow[t]{2}{*}{ Ac } & & & 172.5 & - & & \\
\hline & & & 20.5 & $1.93(3 \mathrm{H}, \mathrm{s})$ & & \\
\hline
\end{tabular}

\section{Experimental}

\subsection{General experimental procedures}

Melting points were recorded with a Schorpp Gerätetechnik apparatus. ${ }^{1} \mathrm{H}$ and ${ }^{13} \mathrm{C}$ NMR spectra were recorded on a Bruker Avance III 600 spectrometer equipped with a cryoprobe $\left({ }^{1} \mathrm{H}\right.$ at $600 \mathrm{MHz}$ and ${ }^{13} \mathrm{C}$ at $\left.150 \mathrm{MHz}\right)$. 2D NMR experiments were recorded by means of standard Bruker microprograms (Xwin-NMR version 2.1 software TopSpin 3). Chemical shifts $(\delta)$ are reported in parts per million (ppm) using the residual solvent signals 
as secondary reference relatively to TMS $(\delta=0)$, while the coupling constants ( $J$ values) are given in Hertz (Hz). TOF-ESIMS and HR-TOFESIMS spectra were recorded using a Micromass Q-TOF micro instrument (Manchester, UK) equipped with an electrospray source. The samples were introduced by direct infusion in a solution of $\mathrm{MeOH}$ at a rate of 5 $\mu \mathrm{L}$ min-1. Column chromatography was run on Merck silica gel 60 (70-230 mesh) and gel permeation on Sephadex LH-20 while TLC was carried out on silica gel GF254 pre-coated plates with detection accomplished by spraying with $50 \% \mathrm{H}_{2} \mathrm{SO}_{4}$ followed by heating at 100 ${ }^{\circ} \mathrm{C}$, or by visual inspection under UV lamp at 254 and $365 \mathrm{~nm}$.

\subsection{Plant material}

The aerial parts of G. grandulosum were collected at FOTO Village (Menoua Division, Western region of Cameroon) in November 2015. Authentication was done by Mr. Fulbert Tadjouteu, a Botanist of the Cameroon National Herbarium, Yaoundé, where a voucher specimen $\left(\mathrm{N}^{\mathrm{o}} 65631 / \mathrm{HNC}\right)$ has been deposited.

\subsection{Extraction and isolation.}

The air-dried plant material $(4 \mathrm{~kg})$ was powdered and extracted at room temperature with methanol ( $3 \times 20 \mathrm{~L}, 72 \mathrm{~h})$. The solvent was evaporated under reduced pressure, leaving an extract $(240 \mathrm{~g})$. Part of this extract $(235 \mathrm{~g})$ was suspended in water $(300 \mathrm{~mL})$ and successively extracted with equal volumes $(500 \mathrm{~mL})$ of ethyl acetate (EtOAc) and $n$-BuOH yielding respectively $37 \mathrm{~g}$ and $13 \mathrm{~g}$ fractions after evaporation to dryness. A part of the $n$ $\mathrm{BuOH}$ fraction $(10 \mathrm{~g})$ was subjected to silica gel column chromatography gradient using EtOAc-MeOH $(100: 0 \rightarrow 0: 100)$ graduated elution. 33 fractions of $150 \mathrm{~mL}$ each were collected and combined on the basis of their TLC profiles to give 6 fractions: A (1-2), B (49), C (10-18), E (19-24) and F (25-33). Fraction B (1.5 g) was purified on sephadex LH-20 column eluted with methanol to give compound $4(15.3 \mathrm{mg})$. Fraction C (2.1 g) and D (3.2 g) were respectively purified on sephadex LH-20. Fractions of $10 \mathrm{~mL}$ were collected and combined on the basis of TLC profiles to give 4 sub-fractions $C_{1}, C_{2}, D_{1}$ and $D_{2}$. Subfractions $C_{2}(1.2 \mathrm{~g})$ and $\mathrm{D}_{2}(500 \mathrm{mg})$ were combined and subjected to silica gel column chromatography using EtOAc-MeOH (95:5) as eluent to give compounds 1 (45.5 mg), 2 $(25.2 \mathrm{mg})$ and $\mathbf{6}(35.2 \mathrm{mg})$. Fraction E (1.3 g) yielded compounds $3(35 \mathrm{mg})$ and $5(20.5 \mathrm{mg})$ after multiple chromatographic steps over silica gel using EtOAc-MeOH- $\mathrm{H}_{2} \mathrm{O}$ (9-1-0.5) and sephadex LH-20 using $\mathrm{MeOH}$, while compound 7 (40.1 mg) was obtained after purification of fraction $\mathrm{F}(0,9 \mathrm{~g})$ by gel column chromatography on silica gel eluted with EtOAc-MeOH$\mathrm{H}_{2} \mathrm{O}$ (8-2-1).

\subsection{New compounds}


Granduloside A: yellow powder; m.p. $=181.8{ }^{\circ} \mathrm{C} ;{ }^{1} \mathrm{H}$ and ${ }^{13} \mathrm{C}-\mathrm{NMR}$ data, see Tables $1 ;[\alpha]_{\mathrm{D}}$ -3.4 (MeOH, c 0.29); IR (KBr) $v_{\max }\left(\mathrm{cm}^{-1}\right)$ 3350-3300, 1070, $1040(\mathrm{OH}), 1643(\mathrm{C}=\mathrm{O}), 1605$, 1580, 1520 (C=C aromatic), 1650 (C-O); HR-TOFESIMS (positive ion mode) $m / z: 587.1370$ $[\mathrm{M}+\mathrm{Na}]^{+}$(calcd. for $\mathrm{C}_{26} \mathrm{H}_{28} \mathrm{O}_{14} \mathrm{Na} 587.1377$ ).

Granduloside B: yellow amorphous powder; ${ }^{1} \mathrm{H}$ and ${ }^{13} \mathrm{C}-\mathrm{NMR}$ data, see Tables $1 ;[\alpha]_{\mathrm{D}}-30.1$ $\left(\mathrm{MeOH}, c\right.$ 0.08); IR (KBr) $v_{\max }\left(\mathrm{cm}^{-1}\right)$ 3350-3300, 1070, $1045(\mathrm{OH}), 1648(\mathrm{C}=\mathrm{O}), 1610,1580$, $1525(\mathrm{C}=\mathrm{C}$ aromatic), $1648(\mathrm{C}-\mathrm{O}$ ); HR-TOFESIMS (positive ion mode) $\mathrm{m} / \mathrm{z}: 629.1471$ $[\mathrm{M}+\mathrm{Na}]^{+}$(calcd. for $\mathrm{C}_{28} \mathrm{H}_{30} \mathrm{O}_{15} \mathrm{Na} 629.1482$ ).

Granduloside C: yellow amorphous powder; ${ }^{1} \mathrm{H}$ and ${ }^{13} \mathrm{C}$-NMR data, see Tables $1 ;[\alpha]_{\mathrm{D}}-37.7$ $\left(\mathrm{MeOH}, c\right.$ 0.58); IR (KBr) $v_{\max }\left(\mathrm{cm}^{-1}\right)$ 3350-3300, 1070, $1040(\mathrm{OH}), 1643(\mathrm{C}=\mathrm{O}), 1605,1580$, $1520(\mathrm{C}=\mathrm{C}$ aromatic), $1650(\mathrm{C}-\mathrm{O})$; HR-TOFESIMS (negative ion mode) m/z: 687.1226 [M$\mathrm{H}^{-}$(calcd. for $\mathrm{C}_{28} \mathrm{H}_{31} \mathrm{O}_{18} \mathrm{~S}$ 687.1231).

\subsection{Acid hydrolysis and determination of absolute configuration of monosaccharides}

Compounds 1-3 (15 mg) were respectively dissolved in $\mathrm{MeOH}-2 \mathrm{~N} \mathrm{HCl}(1: 4)(10 \mathrm{~mL})$ and refluxed at $80{ }^{\circ} \mathrm{C}$ for $3 \mathrm{~h}$. After removal of $\mathrm{MeOH}$ under reduced pressure, the aqueous layer was extracted with $\mathrm{CH}_{2} \mathrm{Cl}_{2}(3 \times 5 \mathrm{~mL})$. The combined $\mathrm{CH}_{2} \mathrm{Cl}_{2}$ extracts were washed with $\mathrm{H}_{2} \mathrm{O}$ and evaporated to dryness to afford the aglycones ( 3.5 and $4 \mathrm{mg}$ respectively). The aqueous layer was neutralized with dilute $\mathrm{NaOH}$ and concentrated to dryness. The resultant residue was dissolved in pyridine $(1 \mathrm{~mL})$, then $\left(\mathrm{CH}_{3}\right)_{3} \operatorname{SiNHSi}\left(\mathrm{CH}_{3}\right)_{3}(1 \mathrm{~mL})$ was added. After $10 \mathrm{~min}$ at room temperature, the solution was blown to dryness under a stream of nitrogen. The residue was dissolved in diethyl ether and then subjected to chiral GC-MS analysis. The monosaccharides in compounds $\mathbf{1}$ and $\mathbf{2}$ were found to be D-xylose and DApiose, while those of compound $\mathbf{3}$ were identified as D-glucose and L-rhamnose by comparison of their retention times with literature values (Hara et al., 1987).

\section{Acknowledgments}

The authors are grateful to the University of Dschang for financing some consumables used in this work, to the "Service Commun d'Analyses" and "Groupe Isolement et Structure", to the "Institut de Chimie Moléculaire de Reims" for the spectroscopic and spectrometric analysis on the ESIMS et NMR equipement of the PlAnet Platform. The EUprogramme FEDER to the PIAneT CPER project is gratefully acknowledged. 


\section{References}

Agrawal, P. K., 1992. NMR spectroscopy in structural elucidation of oligosaccharides and glycosides. Phytochemistry 31, 3307-3330.

Barker, R.M., 1986. Graptophyllum Nees. Journal of the Adelaide Botanic Gardens 9,156166.

Corrêa, G. M. Alcântara A. F. C., 2012. Chemical constituents and biological activities of species of Justicia - a review. Brazilian Journal of Pharmacognosy 22, 220-238.

Facundo, V. A., Azevedo, M. S., Rodrigues, R. V., Do Nascimento, L. F., Militão, J. S. L. T., Da Silva, G. V. J., Braz-Filho, R., 2012. Chemical constituents from three medicinal plants: Piper renitens, Siparuna guianensis and Alternanthera brasiliana. Brazilian Journal of Pharmacognosy 22, 1134-1139.

Hara, S., Okabe, H., Mihashi, K., 1987. Gas-liquid chromatographic separation of aldose enantiomers as trimethylsilyl ethers of methyl 2 (polyhydroxyalkyl) thiazolidine4(R)-carboxylates. Chemical and Pharmaceutical Bulletin 35, 501-506.

Hee-Jeong, M., Tae-Seong, L., Young-Soo, B., 2014. Structure Determination of Sucrose by Acetylation and Acid Hydrolysis. Journal of the Korean Wood Science and Technology 42 183-192.

Hiroshi, N., Naoyuki, K., Mitsuru, Y., Hiroshi, O., Rika, I., Takuji, T., 2011. Isolation and Identification of Flavonoids Accumulated in Proanthocyanidin-free Barley. Journal of Agricultural and Food Chemistry 59, 9581-9587

Kasahara, Y. S., Mangunkawatjia, S., 1986. Medicinal Herb index in Indonesia, Eisai Indonesia, p. 318

Koffi, E. N., Le Guernevéc, C., Lozanoa, P. R., Meudecc, Adjéd, F. A., Bekrob,Y. A., Lozanoa, Y. F., 2013. Polyphenol extraction and characterization of Justicia secunda Vahl. leaves for traditional medicinal uses. Industrial Crops and Products 49, 682-689.

Markham, K. R., Chari, V. M., 1982. Carbon-13 NMR spectroscopy of flavonoids. In: The Flavonoids: Advances in Research (Harborne J.B. and Mabry T.J., eds.). Chapman and Hall, London.

Markham, K. R., Ternai, B., Stanley, R., Geiger, H., Mabry, T. J., 1978. Carbon-13 NMR studies of flavonoids. III. Naturally occurring flavonoid glycosides and their acylated derivatives. Tetrahedron 34, 1389-1397. 
Mona-Antonia, B., Hanns H., 1999. Flavonol glycosides from Eschscholtzia californica. Phytochemistry 50, 329-332.

Perry, L. M., 1980. Medicinal plants of East and South-East Asia; Attributed Properties and Uses MIT press, Cambridge, United States and London, p. 2.

Zhang, X.L., Guo, Y.S., Wang, C.H., Li, G.Q., Xu, J.J., Chung, H.Y., Ye, W.C., Li. Y.L., Wang, G.C., 2014. Phenolic compounds from Origanum vulgare and their antioxidant and antiviral activities. Food Chemistry. 152, 300-306. 